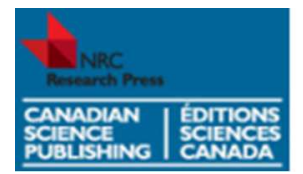

Canadian Journal of

Fisheries and Aquatic Sciences

Journal canadienne des

sciences halieutiques et

aquatiques

\title{
Impact of hypoxia on the metabolism of Greenland halibut (Reinhardtius hippoglossoides)
}

\begin{tabular}{|r|l|}
\hline Journal: & Canadian Journal of Fisheries and Aquatic Sciences \\
\hline Manuscript ID: & cjfas-2012-0327.R1 \\
\hline Manuscript Type: & Article \\
\hline Complete List of Authors: & $\begin{array}{l}\text { Prinet, Aurélie; Université du Québec à Rimouski, Institut des sciences de } \\
\text { la mer de Rimouski } \\
\text { Vagner, Marie; UMR LIENSs 7266, Institut du Littoral et de I’Environnement } \\
\text { Chabot, Denis; Pêches et Océans Canada, Institut Maurice Lamontagne } \\
\text { Audet, Céline; Université du Québec à Rimouski, Institut des sciences de la } \\
\text { mer de Rimouski }\end{array}$ \\
\hline Keyword: & $\begin{array}{l}\text { aerobic scope, specific dynamic action, standard metabolic rate, critical } \\
\text { oxygen threshold }\end{array}$ \\
\hline
\end{tabular}

\section{SCHOLARONE \\ Manuscripts}




\section{Impact of hypoxia on the metabolism of Greenland halibut}

(Reinhardtius hippoglossoides)

4 Aurélie Dupont-Prinet ${ }^{1}$, Marie Vagner ${ }^{1,3}$, Denis Chabot $^{2}$ and Céline Audet $^{1}$

$6{ }^{1}$ Institut des Sciences de la Mer - Université du Québec à Rimouski, 310, allée des Ursulines,

7 Rimouski, QC, G5L 3A1, Canada

$8{ }^{2}$ Institut Maurice Lamontagne, Pêches et Océans Canada, 850 route de la Mer, C.P. 1000, Mont-

9 Joli, QC, G5H 3Z4, Canada

$10{ }^{3}$ Present address: UMR LIENSs 7266, Institut du Littoral et de 1'Environnement, 2 rue Olympe

11 de Gouges 17000 La Rochelle, France

13 Author for correspondence:

14 Aurélie Dupont-Prinet

15 Institut des sciences de la mer de Rimouski (ISMER)

16 Université du Québec à Rimouski (UQAR)

17310 , allée des Ursulines

18 Rimouski (Québec)

19 G5L 3A1

$20 \quad$ Fax (418) 724-1842

21 Aurelie.Dupont-Prinet@uqar.qc.ca 


\section{Abstract}

24 Greenland halibut, especially juveniles, are frequently found in severely hypoxic areas (18-25\%

25 saturation) of the St. Lawrence Estuary. We investigated the tolerance of this species to hypoxia

26 and evaluated the consequences of low oxygen levels on metabolic capacity. At $5^{\circ} \mathrm{C}$, juveniles

27 had a higher critical oxygen threshold than adults (15 vs 11\% saturation), indicating that they

28 were less tolerant to hypoxia. Severe hypoxia (19\% saturation) did not affect the juveniles'

29 standard metabolic rate but significantly reduced (by 55\%) their maximum metabolic rate

30 compared to normoxia. Consequently, the aerobic scope was reduced by $72 \%$ in hypoxia

31 compared to normoxia. In juveniles, severe hypoxia increased the duration of digestive processes.

32 The decrease in aerobic scope in hypoxia and the determination of $\mathrm{O}_{2 \text { crit }}$ at a saturation level close

33 to actual field DO values strongly suggest that juveniles from the St. Lawrence Estuary are living

34 at the edge of their metabolic capacity. Consequently, the growth and distribution of Greenland

35 halibut could be affected if there are further declines in dissolved oxygen availability.

37 Key words: aerobic scope, specific dynamic action, standard metabolic rate, critical oxygen 38 threshold.

\section{Résumé}

41 Les flétans du Groenland, en particulier les juvéniles, sont fréquemment pêchés dans les zones

42 hypoxiques (18-25\% saturation) de 1'Estuaire du St. Laurent. L'objectif de cette étude était

43 d'évaluer la tolérance à l'hypoxie chez cette espèce ainsi que les conséquences des faibles

44 niveaux d'oxygène sur sa capacité métabolique. À $5^{\circ} \mathrm{C}$, les juvéniles ont un seuil critique

45 d'oxygène supérieur à celui des adultes (15 vs $11 \%$ saturation), indiquant qu'ils sont moins

46 tolérants à l'hypoxie. L'hypoxie sévère (19\% saturation) n'a pas affecté le taux métabolique 
47 standard des juvéniles, mais a réduit significativement (de $55 \%$ ) leur taux métabolique maximal 48 par rapport à la normoxie. Par conséquent, le registre aérobie a été réduit de $72 \%$ en hypoxie par 49 rapport à la normoxie. Chez les juvéniles, l'hypoxie sévère augmente la durée du processus de 50 digestion. La réduction du registre aérobie en hypoxie et la détermination du seuil critique 51 d'oxygène à des niveaux près de ceux actuellement présents dans l'estuaire du Saint-Laurent 52 suggèrent que les juvéniles ont peu de marge de manœuvre sur le plan métabolique. 53 Conséquemment, toute nouvelle dégradation des conditions d'oxygénation pourrait affecter la 54 croissance et la distribution du flétan du Groenland. 


\section{Introduction}

58 Greenland halibut, Reinhardtius hippoglossoides (Walbaum), is an important commercial species

59 in the North Atlantic, and for the last 20 years it has been the most important commercial

60 demersal fish in the Estuary and Gulf of St. Lawrence (EGSL), accounting for 58\% of fish

61 catches in terms of biomass (DFO 2011). Recently, Ait Youcef et al. (2013) have shown that the

62 St. Lawrence estuary is the major nursery area for the EGSL population and that habitats selected

63 by Greenland halibut are characterized by low dissolved oxygen (DO) levels. The strong

64 association between higher fish densities and the low DO concentrations suggest a high tolerance

65 of Greenland halibut to hypoxia.

67 Between 1930 and the early 1980s, DO levels decreased by half in the deep water of the St.

68 Lawrence Estuary due to an increase in the proportion of warm, oxygen-poor North Atlantic

69 central water coming into the system and an increase in organic matter flow (Coote and Yeats

70 1979; Gilbert et al. 2005, 2007; Thibodeau et al. 2006, 2010; Genovesi et al. 2011). Since the

71 mid-1980s, DO levels in water deeper than $150 \mathrm{~m}$ in the St. Lawrence Estuary have been stable at

72 around 18-25\% saturation (sat. hereafter) (Gilbert et al. 2007). However, climate change and

73 increasing human population have the potential to further accentuate hypoxia in the St. Lawrence

74 system.

76 Hypoxia in estuaries and coastal waters is known to affect biodiversity (Breitburg 2002; Switzer

77 et al. 2009; Zhang et al. 2010a). Habitat suitability, behaviour, and physiology could all be

78 affected, and effects vary according to species, life history stage, and predator-prey interactions

79 among others (Breitburg 2002; Eby et al. 2005; Switzer et al. 2009; Brandt et al. 2011). If we 
80 consider physiological effects and fish performance, the DO level directly impacts metabolism

81 (Fry 1971; Brett 1979) and, consequently, growth, activity level, and the ability to process meals

82 (Stewart et al. 1967; Andrews et al. 1973; Weber and Kramer 1983; Cech et al. 1984; Pedersen

83 1987; Van den Thillart et al. 1994; Chabot and Dutil 1999; Dupont-Prinet et al. 2009; Zhang et

84 al. 2010b). In the context of global changes, climate change may directly impact water

85 temperature, which will impact hypoxia events (frequency and duration) and the metabolic

86 performance of fishes (Pörtner and Peck 2010). From the 1930s to the 1980s, the bottom waters

87 of the St. Lawrence Estuary warmed by $1.65^{\circ} \mathrm{C}$ (Gilbert et al. 2005); this increased bacterial

88 metabolism, which played a role in DO decrease (Genovesi et al. 2011). Because metabolic rates

89 directly scale with temperature in exothermic organisms, the increase in metabolism associated

90 with climate warming could reduce the body size of ectotherms unless organisms can compensate

91 with greater food intake or the reallocation of caloric resources (e.g., Sheridan and Bickford

92 2011). In modifying the capacity-limitation of a species, climate change makes the species more

93 vulnerable and has a direct impact on productivity, food webs, and biodiversity (Pörtner 2010).

94 To determine how these changes will impact specific environments represents huge scientific

95 challenges, and one of the first steps to achieving this is to understand how each species tolerates

96 or may adapt to hypoxic conditions.

98 The aim of this study was to determine the tolerance of Greenland halibut to hypoxia and to

99 evaluate the consequences of low DO levels on metabolic capacity. To do so, we determined the

100 standard metabolic rate (SMR) and the critical oxygen threshold $\left(\mathrm{O}_{2 \text { crit }}\right)$ in both juvenile and adult

101 Greenland halibut. The maximum metabolic rate (MMR) and the specific dynamic action (SDA;

102 the transient post-prandial increase in metabolic rate) were also investigated in juveniles under 103 severely hypoxic conditions. 


\section{Materials and Methods}

\section{Experimental animals}

108 Adult Greenland halibut were caught by long-line fishermen near Rivière-au-Renard (QC,

109 Canada) whereas juveniles were caught by trawling during Fisheries and Oceans Canada (DFO)

110 fishing operations in the St. Lawrence Estuary. Fish were held for several months under a natural

111 photoperiod at the Maurice Lamontagne Institute (Mont-Joli, QC, Canada) in rearing tanks

112 supplied with natural seawater (salinity $\sim 28$; DO $\sim 100 \%$ sat.) maintained at $5^{\circ} \mathrm{C}$. Animals were

113 fed three times a week to satiation with capelin (Mallotus villosus) and shrimp (Pandalus sp.).

114 Fish fasted for one week before all experiments. However, for the SDA experiments, fasted fish 115 were force-fed $15 \mathrm{~min}$ before being introduced into the respirometer (see below). Prior to any 116 experiment, Stress Coat ${ }^{\circledR}\left(0.26 \mathrm{~mL} \cdot \mathrm{L}^{-1}\right.$; Mars Fishcare North America Inc., PA, USA) was added 117 to the water to reduce mucus loss in fish.

119 Experimental methods complied with the regulations of the Canadian Council on Animal Care 120 and were approved by the Maurice Lamontagne Institute and the Université du Québec à 121 Rimouski animal care committees.

\section{Experimental setup}

124 Five respirometers (48.77 L for adults; $2.18 \mathrm{~L}$ for juveniles) were placed in a $1359 \mathrm{~L}$ rearing tank

125 provided with a constant flow of aerated seawater at $5^{\circ} \mathrm{C}$. Incoming water and recycled water

126 from the tank flowed through a gas-exchange column. Oxygen partial pressure $\left(\mathrm{PO}_{2}\right)$ was 
127 continuously recorded using a regulator system (Oxy-Reg, Loligo Systems, Denmark; Mini DO

128 galvanic probe, OxyGuard International A/S, Denmark). Nitrogen was injected into the column

129 through a solenoid valve as needed to keep DO within the desired range. When normoxia was

130 desired, air was continuously injected into the column. Oxygen pressure was converted to percent

131 saturation relative to the pressure of oxygen in the air at standard atmospheric pressure after

132 correcting for vapour pressure at $5^{\circ} \mathrm{C}$ and salinity of 28 . The tank containing the respirometers

133 was isolated in a room kept dark at night and in low light in daytime (red lights, with some white

134 light penetrating from surrounding labs). The tank was shielded with opaque curtains to further

135 prevent visual disturbance of the fish.

136

137 Oxygen uptake $\left(\mathrm{MO}_{2}\right.$, in $\left.\mathrm{mg} \mathrm{O} \mathrm{O}_{2} \cdot \mathrm{h}^{-1} \cdot \mathrm{kg}^{-1}\right)$ in each respirometer was measured by intermittent-flow 138 respirometry (Steffensen 1989): respirometers were flushed with normoxic or hypoxic water for 5

$139 \mathrm{~min}$ and closed for $15 \mathrm{~min}$. This cycle was repeated for as long as the fish were in the 140 respirometers. The linear decline in DO observed during the last 13 min was used to calculate $141 \dot{\mathrm{MO}}_{2}$ according to equation 2 of Steffensen (1989) and equation 8 of Garcia and Gordon (1992)

142 for oxygen solubility. DO was monitored every second using a fibre optic oxygen meter (one143 channel Fibox 3 or four-channel Oxy-4 Mini, PreSens, Germany) connected to a Daq 1 or Daq 4 144 automated control system associated with the AutoResp ${ }^{\mathrm{TM}} 1$ v1.6.0 or AutoResp ${ }^{\mathrm{TM}}$ v1.8.0 145 software (Loligo Systems, Denmark), respectively. For each experiment, four fish were 146 individually transferred to their own respirometer in a plastic bag filled with tank water; air 147 exposure was avoided so that gills and metabolism were not altered (Zahl et al. 2010). A fifth 148 respirometer was used as a control. Background respirometer $\dot{\mathrm{MO}}_{2}$ was measured before the fish 
149 was introduced into the respirometer and after it was removed. $\mathrm{MO}_{2}$ values were corrected for 150 background respiration.

\section{Standard metabolic rate (SMR)}

153 SMR corresponds to the minimal metabolic demands required to sustain life in fasting and

154 "resting" fish (Fry 1971; Brett and Groves 1979). There is no established method to calculate

155 SMR. We used a quantile approach in our study because it seemed more robust than other 156 methods proposed in the literature since it is less influenced by spontaneous activity (Daoud et al.

157 2007; Dupont-Prinet et al. 2010; Nelson and Chabot 2011). This approach assumes that a certain 158 proportion of the observed $\dot{M}_{2}$ values are actually below true SMR because of measurement 159 errors and biological variability. The quantile splits the dataset into the $\mathrm{q}$ smallest and the $1-\mathrm{q}$ 160 largest values, where $\mathrm{q}$ is a proportion chosen by the experimenter. In other studies, $\mathrm{q}$ varied from 1610.05 (Van den Thillart et al. 1994) to 0.25 (Dorcas et al. 2004). In our study, SMR was estimated 162 for all fish by calculating the quantile $(\mathrm{q}=0.15)$ of the $\mathrm{M}_{2}$ values obtained after a $6 \mathrm{~h}$ 163 acclimation period (recovery from handling stress) and for at least $42 \mathrm{~h}$ when fish were left 164 undisturbed. With this setting, SMR passed through the middle of the data points in periods of 165 low $\dot{\mathrm{M}} \mathrm{O}_{2}$.

\section{Critical $\mathbf{O}_{2}$ limit $\left(\mathbf{O}_{2 \text { crit }}\right)$}

168 This experiment was conducted on 14 adults and 12 juveniles. Oxygen uptake was measured for 169 at least $48 \mathrm{~h}$ in normoxia to estimate SMR. After this initial period, DO was gradually decreased 170 from 100 to $10 \%$ (5\% sat. if required) over a period of approximately $10 \mathrm{~h}$. The AutoResp ${ }^{\mathrm{TM}}$ 171 software calculated $\dot{\mathrm{MO}}_{2}$ in real time. The experiment was stopped for a given fish when it 
172 showed signs of respiratory distress, i.e., when $\dot{M}_{2}$ decreased below SMR for one hour. To

173 ensure that fish were not in extreme distress, we regularly visually checked them during this

174 period using a red light; fish typically remained quiescent throughout. At the end of each trial,

175 fish were anaesthetized (metomidate hydrochloride, Aquacalm ${ }^{\mathrm{TM}} ; 5 \mathrm{mg} \cdot \mathrm{L}^{-1}$, Western Chemical

176 Inc., WA, USA), weighed, and FL measured. In our study, the $\mathrm{O}_{2 \text { crit }}$ refers to the DO level below

177 which an animal cannot indefinitely maintain its SMR, so it cannot sustain its vital functions

178 (Wang et al. 2009). $\mathrm{O}_{2 \text { crit }}$ was calculated using an algorithm written in $\mathrm{R}$ (R Development Core

179 Team 2011) to identify data points falling below SMR and a linear regression was fit; the

180 intersection of this line with the horizontal line represents SMR (Fig. 1).

181

182 Maximum metabolic rate (MMR) and aerobic scope (AS)

183 MMR corresponds to the highest measure of $\dot{M}_{2}$, which is usually associated with intense 184 exercise. AS represents the metabolic framework within which the animal must meet all its 185 metabolic needs. We measured the impact of hypoxia on MMR and AS in juvenile fish only. In 186 addition to normoxia (control), targeted DO levels were 35, 25, and 20\% sat. However, 187 incomplete mixing due to the large size of the rearing tank and possible drift of the galvanic Mini 188 probe caused differences between DO measured in the ambient tank and DO in the respirometers 189 at the end of the flush periods. DO at the end of the flush period was used to represent the DO 190 experienced by the fish (more precisely, the experienced DO for each cycle was the average DO 191 value from the data used to calculate $\dot{\mathrm{M}}_{2}$ ); the average achieved experimental levels were 28, 23, 192 and $19 \%$ sat. 
194 Some fishes, including Greenland halibut, do not swim in Brett-type swim tunnels. For such fish,

195 maximum oxygen consumption can be measured following exhausting activity that requires

196 oxygen debt repayment (Lucas and Priede 1992; Reidy et al. 1995; Liao and Lucas 2000).

197 Juveniles were acclimated for one hour to the experimental oxygen level. They were then

198 transferred to a circular tank (to avoid potential injuries in corners) where they were repeatedly

199 flipped upside down until exhaustion ( $15 \mathrm{~min}$ in normoxia and $\sim 5 \mathrm{~min}$ in hypoxia), which we

200 defined as when fish were flipped onto their backs and could no longer right themselves. The

201 time of exhaustion was precisely recorded. To measure post-exercise $\dot{M}_{O_{2}}$ and $\dot{M}_{O_{2}}$ during

202 spontaneous activity, fish were then immediately transferred into respirometer chambers. $\dot{M}_{\mathrm{O}_{2}}$

203 was monitored using the automatic procedure described above. After four days of recording, fish

204 were lightly anaesthetized in metomidate hydrochloride (Aquacalm ${ }^{\mathrm{TM}} ; 5 \mathrm{mg} \cdot \mathrm{L}^{-1}$ ), weighed, and

205 FL measured. For each fish, post-exercise $\dot{\mathrm{M}} \mathrm{O}_{2}$ was calculated. Usually, $\dot{\mathrm{M}}_{2}$ declined rapidly

206 after the fish was placed into the respirometer. MMR was estimated using two different methods:

207 1) because $\dot{M}_{2}$ usually declined rapidly after the fish was placed into the respirometer, the

208 highest of the first three $\dot{M}_{2}$ values was taken to represent post-exercise $\dot{\mathrm{M}} \mathrm{O}_{2}$ (Fig. 2A); 2)

209 because juvenile Greenland halibut often displayed marked circadian cycles of $\dot{M}_{2}$, the 0.99

210 quantile of the $\dot{\mathrm{M}}_{2}$ values recorded for each fish, excluding the first three values used to

211 calculate post-exercise $\dot{\mathrm{M}}_{2}$, was used to estimate maximum $\dot{\mathrm{MO}}_{2}$ during spontaneous activity or

212 stress (Fig. 2B). Because activity level was not measured, the maximum value may have been

213 caused by measurement error instead of activity. There were usually three or four values of $\dot{M}_{2}$

214 above the 0.99 quantile, making it more likely that this estimate of high $\dot{\mathrm{M}}_{2}$ was indeed caused

215 by spontaneous activity or stress, and not measurement error. A lower quantile was judged 
216 inadequate considering that spontaneous activity took place only occasionally in the

217 respirometers.

219 The highest of either the post-exercise $\dot{\mathrm{MO}_{2}}$ (20 fish) or maximum spontaneous $\dot{\mathrm{M}} \mathrm{O}_{2}$ (26 fish) was

220 retained as our best estimate of MMR for a given fish. The rationale for using these two methods

221 is that post-exercise $\dot{\mathrm{M}}_{2}$ measurement does not take into account circadian variations in

222 spontaneous activity even though it is the most classical approach used in literature. Because

223 some fish reached higher $\dot{\mathrm{M}}_{2}$ during spontaneous activity than after exercise, using both

224 methods reduced the risk of underestimating MMR. SMR was also estimated for each fish as

225 described previously. Aerobic scope (AS) was calculated as the difference between MMR and

226 SMR (Fry 1971).

\section{Specific dynamic action (SDA)}

229 SDA corresponds to the costs of digestive processes, i.e., digestion, assimilation, and

230 transformation of nutrients - in particular the synthesis, turnover, and accretion of proteins - in

231 all body tissues (Jobling 1981, 1983; McCue 2006; Secor 2009; Dupont-Prinet et al. 2009, 2010).

232 It represents one of the major metabolic costs of a fish. SDA was measured on juveniles only. We

233 planned to study SDA at 100, 35, 25, and 20\% sat. but examined the two extremes first. For the

234 reasons given above, the average DO level ended up being 21 instead of $20 \%$. Because of the

235 very limited responses observed at $21 \%$ sat. relative to normoxia, the two intermediate levels (35

236 and $25 \%$ sat.) were dropped. To reduce stress at the beginning of each experiment, FL was

237 measured one week before the experiment to estimate stomach volume for ration determination.

238 Maximal food ration (g) was estimated by quantile regression (R package quantreg; Koenker 
239 2011) of the cubic root of stomach mass as a function of fish length $(\mathrm{cm})$, with q set to $0.85(\mathrm{~N}=$ 2409249 stomach contents collected between 1993 and 2008 in the Estuary and Gulf of St.

241 Lawrence; D. Chabot, DFO Canada: denis.chabot@dfo-mpo.gc.ca, unpublished data, 2010): 242 maximum stomach content mass $=(0.21455+0.0057 * \text { length })^{3}$. In this study, the food ration 243 (capelin fillets) was set to $90 \%$ of maximum stomach content mass to avoid regurgitation. This 244 corresponded to $\sim 4 \%$ of body mass.

246 Greenland halibut did not eat spontaneously in the respirometer, even when they had fasted for 247 one week. For this reason, food was offered to the fasted fish in a large tank in normoxia where 248 they ate voluntarily. To avoid regurgitation, fish were kept in the tank for 15 min before being 249 transferred to individual respirometers (21 or $100 \%$ sat.). $\dot{M}_{2}$ was measured until it reached a 250 stable level for at least $48 \mathrm{~h}$ (about 1 week). Fish were then anaesthetized with metomidate 251 hydrochloride (Aquacalm ${ }^{\mathrm{TM}} ; 5 \mathrm{mg} \cdot \mathrm{L}^{-1}$ ) until breathing movements ceased. They were then 252 weighed and FL measured. Unlike the other experiments, SMR was estimated from the period of 253 stable $\mathrm{MO}_{2}$ following SDA (minimum $48 \mathrm{~h}$ ). SDA was calculated using an algorithm written in R 254 (R Development Core Team 2011) and the quantreg package (Koenker 2005, 2011). A non255 parametric quantile regression (function rqss of quantreg) was fitted to the postprandial $\dot{\mathrm{M}}_{2}$ 256 measurements, and SDA was deemed terminated when the fit reached SMR $+10 \%$ (Fig. 3) 257 (Chabot and Claireaux 2008; Dupont-Prinet et al. 2010). $\tau$ was set to the value of q used to 258 compute $\operatorname{SMR}(0.15)$, and therefore the same proportion of $\dot{\mathrm{MO}_{2}}$ values was found below the 259 fitted curve during SDA as during SMR. Juvenile Greenland halibut tend to be more active at 260 night, and such bouts of activity could influence the computation of SDA parameters (see Fig. 2 261 and 3 for examples of nocturnal increases in $\dot{M}_{2}$ likely caused by spontaneous activity). The 
262 parameter $\lambda$ controls the flexibility of the fit and was set to 36 (h) to prevent this. Maximum post-

263 prandial oxygen consumption ( $\dot{\mathrm{M}}_{2}$ peak), amplitude (difference between $\dot{\mathrm{M}}_{2}$ peak and SMR), time

264 to peak ( $\mathrm{T}_{\text {peak }}$ : time after feeding required to reach $\dot{\mathrm{M}}_{2 \text { peak }}$ ), duration (time required to return to

265 SMR + 10\%), and magnitude (area under the curve) of SDA were estimated for each fish (Fig. 3).

\section{Statistical analysis}

268 Normality and homogeneity of variances were verified by Shapiro-Wilks and Brown-Forsythe 269 tests, respectively. MMR and AS data were log transformed to avoid heteroscedasticity. One-way

270 ANOVAs were used to test for the effect of developmental stage (adult and juvenile) or DO level 271 on measures of metabolism. When appropriate, a posteriori Tukey tests were used to compare 272 means $(\alpha=0.05)$. The relationship between SMR of each individual $\left(\mathrm{SMR}_{\text {ind }}, \mathrm{mg} \mathrm{O}_{2} \cdot \mathrm{h}^{-1}\right)$ and 273 body mass was analyzed by linear regression (both variables were log transformed to linearize the 274 relationship and reduce heteroscedasticity). Statistical analyses were performed with the Statistica 275 software package (Statsoft v.6.1, Tulsa, OK, USA).

277 Results

280 SMR was significantly greater in juveniles than in adults (Table 1; $\mathrm{F}_{[1,24]}=117.232, \mathrm{P}<0.001$ ). 281 The relationship between $\mathrm{SMR}_{\text {ind }}$ and wet body mass is described by the equation $282 \log \left(\mathrm{SMR}_{\text {ind }}\right)=0.7708 \cdot \log ($ mass $)-1.0247$ (Fig. 4). Although this study was not designed to 283 establish the relationship between SMR and body mass, and the entire range of body masses was 284 not covered, the slopes obtained from each size group $(0.91 \pm 0.18$ for juveniles and $0.98 \pm 0.18$ 
285 for adults, slope \pm SE) did not differ significantly since their 95\% confidence intervals (based on

286 SE x 2) overlapped. The slope for both groups combined was lower but is based on a broader

287 range of mass values, thus it is a more reliable estimate of the allometric exponent $(0.77 \pm 0.02)$.

288 Its confidence interval also overlapped with that of the two groups taken separately.

290 O $_{\text {crit }}$

291 Greenland halibut were tolerant to DO low levels, with $\mathrm{O}_{2 \text { crit }}$ below $15 \%$ sat. (Table 1). $\mathrm{O}_{\text {2crit }}$ was 292 significantly higher for juveniles than for adults (Table 1; $\mathrm{F}_{[1,24]}=10.718, \mathrm{P}=0.003$ ), indicating 293 that juveniles were less tolerant to hypoxia than adults.

Aerobic metabolism

296 The SMR of juveniles was not affected by DO levels (Table 2; $\mathrm{F}_{[3,42]}=2.711, \mathrm{P}=0.057$ ). While

297 MMR significantly decreased (55\%) from normoxia to hypoxia (Table $2 ; \mathrm{F}_{[3,42]}=30.645, \mathrm{P}<$ 298 0.001), it remained similar between the different levels of hypoxia. AS in normoxia was 299 significantly greater than at any hypoxic level (Table 2; $\mathrm{F}_{[3,42]}=31.779, \mathrm{P}<0.001$ ). AS was 300 similar at the two intermediate levels ( 23 and $28 \%$ sat.), but it was significantly smaller at $19 \%$ 301 sat. than at any other DO level and represented only $28 \%$ of the AS value calculated in normoxia.

\section{Specific dynamic action (SDA)}

304 In normoxia, $\mathrm{M}_{2}$ increased during SDA until reaching its maximum ( $\left.\mathrm{T}_{\text {peak }}\right)$ about $28 \mathrm{~h}$ after food 305 intake (Table 3). In normoxia, SDA mobilized up to $24 \%$ of AS when calculated under similar 306 conditions (20.91 vs $\left.87.06 \mathrm{mg} \mathrm{O} \mathrm{O}_{2} \cdot \mathrm{h}^{-1} \cdot \mathrm{kg}^{-1}\right)$. The only significant effect of severe hypoxia on SDA 307 was an increase in duration (Table $3 ; \mathrm{F}_{[1,15]}=4.588, \mathrm{P}=0.049$ ). Average SDA traces show that 
308 postprandial $\dot{\mathrm{MO}}_{2}$ tended to be lower in hypoxia than normoxia for the first $72 \mathrm{~h}$ after food 309 ingestion; it remained high for another $30 \mathrm{~h}$ but dropped rapidly after $72 \mathrm{~h}$ for the normoxic 310 group. However, these differences were not significant in our experiment, as shown by the 311 overlapping 95\% confidence bands (Fig. 5). Because of the decrease in MMR, SDA mobilized 312 between 49 and $75 \%$ of AS when calculated at similar hypoxic levels (23 and 19\% sat): 18.33 vs 31337.66 or $24.53 \mathrm{mg} \mathrm{O} \cdot \mathrm{h}^{-1} \cdot \mathrm{kg}^{-1}$ (Tables 2 and 3).

\section{Discussion}

\section{Critical $\mathbf{O}_{2}$ limit}

318 Greenland halibut exhibited an $\mathrm{O}_{2 \text { crit }}$ below 15\% sat. This compares well with hypoxia-tolerant 319 species such as the sole, Solea solea $\left(\mathrm{O}_{2 \text { crit }} \sim 12 \%\right.$ sat.; Van den Thillart et al. 1994), and the 320 pikeperch, Sander lucioperca $\left(\mathrm{O}_{2 \text { crit }}=11 \%\right.$ and $28 \%$ sat., respectively, at $13^{\circ} \mathrm{C}$ and $28^{\circ} \mathrm{C}$; Frisk et 321 al. 2012). In these studies, the sole came from the North Adriatic Sea, which has long periods of 322 hypoxia, and the pikeperch prefers turbid waters and lives in hypoxia during summer months and 323 under the ice during winter. This supports our hypothesis, based on its distribution in the EGSL, 324 that Greenland halibut is an extremely hypoxia-tolerant species. On the contrary, Atlantic cod, 325 Gadus morhua, which is also found in the EGSL, is sufficiently sensitive to hypoxia to now be 326 excluded from the deep waters of the Estuary (D'Amours 1993; Chabot and Claireaux 2008),

327 where DO levels are below the threshold where hypoxia-induced mortality becomes significant in 328 the laboratory (28\% sat.; Plante et al. 1998).

330 Juvenile Greenland halibut proved to be less tolerant to hypoxia than adults. As a general rule, 
331 metabolic rate increases with body mass in fish, and, conversely, mass-specific metabolic rate

332 decreases with mass. This may explain why we found adults to be more hypoxia-tolerant than

333 juveniles. However, in some species such as the sharpsnout sea bream, Diplodus puntazzo, and

334 largemouth bass, Micropterus salmoides (Burleson et al. 2001; Cerezo and García 2004), large

335 individuals have been shown to be less hypoxia-tolerant than small individuals, despite their

336 lower mass-specific metabolic rate. More work is therefore required to describe the mechanism

337 underlying the differences in the hypoxia tolerance between juvenile and adult Greenland halibut.

339 The lower hypoxia tolerance of juvenile Greenland halibut has important ecological implications

340 considering that the Estuary, which is more severely hypoxic than the Gulf, is considered as a

341 nursery habitat for this species (Bourdages et al. 2010; Ait Youcef et al. in press). Field values of

342 DO can be as little as $3 \%$ sat. above the $\mathrm{O}_{2 \text { crit }}$ of juvenile fish: although most measures of bottom-

343 level DO are in the $20-25 \%$ sat. range, values as low as $18 \%$ sat. have been observed (Gilbert et

344 al. 2005, 2007) and juvenile halibut $\mathrm{O}_{2 \text { crit }}$ was $\sim 15 \%$ sat. Considering natural variability in both

345 DO levels in the Estuary and in individual $\mathrm{O}_{2 \text { crit, }}$ the most sensitive fish may already face some

346 habitat exclusion. Our results suggest that even a small decrease in the oxygen saturation could

347 have a major impact on the distribution of this species in the Estuary and Gulf of St. Lawrence.

348 There is a study in progress to determine juvenile growth and stomach content of fish captured in

349 different zones and depths of the St. Lawrence estuary that are characterized by different 350 temperature, salinity, and DO conditions (Ait Youcef pers. comm.). The combination of

351 physiological and ecological data will help provide a better estimation of the species' status in 352 this environment.

354 Aerobic scope of juvenile Greenland halibut in normoxia 
355 In normoxia, the AS $\left(87 \mathrm{mg} \mathrm{O}{ }_{2} \cdot \mathrm{h}^{-1} \cdot \mathrm{kg}^{-1}\right)$ of Greenland halibut was very low compared to pelagic

356 fish, such as European seabass, Dicentrarchus labrax $\left(\sim 200-300 \mathrm{mg} \mathrm{O} \cdot \mathrm{h}^{-1} \cdot \mathrm{kg}^{-1}\right.$; $\mathrm{Chatelier}^{\mathrm{et}}$ al.

357 2005, 2006), Atlantic cod, Gadus morhua (175 $\mathrm{mg} \mathrm{O}{ }_{2} \cdot \mathrm{h}^{-1} \cdot \mathrm{kg}^{-1}$; Jordan and Steffensen 2007), and

358 golden grey mullet, Liza aurata $\left(\sim 1000 \mathrm{mg} \mathrm{O} \cdot \mathrm{h}^{-1} \cdot \mathrm{kg}^{-1}\right.$; Milinkovitch et al. 2012); this is

359 commonly observed in flatfishes (common sole, Solea solea $\left[85 \mathrm{mg} \mathrm{O}{ }^{2} \cdot \mathrm{h}^{-1} \cdot \mathrm{kg}^{-1}\right.$, Van den Thillart

360 et al. 1994, Davoodi and Claireaux 2007; $\sim 10 \mathrm{mg} \mathrm{O} \cdot \mathrm{h}^{-1} \cdot \mathrm{kg}^{-1}$, Lefrançois and Claireaux 2003];

361 turbot, Scophthalmus maximus $\left[\sim 60 \mathrm{mg} \mathrm{O} \cdot \mathrm{h}^{-1} \cdot \mathrm{kg}^{-1}\right.$, Mallekh and Lagardère 2002]). This probably

362 reflects the benthic lifestyle of flatfishes, which may rest on the bottom for several hours

363 (although Greenland halibut feeds on pelagic prey). Although the underestimation of MMR and

364 thus of AS remains a possibility, our estimates of AS for juvenile Greenland halibut are

365 comparable to those of other flatfishes.

366

367 In normoxia, our study shows that SDA almost doubles $\dot{M}_{2}$ relative to SMR and can mobilize up

368 to $24 \%$ of the $\mathrm{AS}$ at $5^{\circ} \mathrm{C}$ and with a meal size close to $4 \%$ of body mass. This value is very close

369 to results found with common sole, Solea solea, where the postprandial $\dot{M}_{2}$ peak never exceeded

$37025 \%$ of the AS at $15^{\circ} \mathrm{C}$, regardless of the size of the meal ingested ( 1.5 or $2.5 \%$ of body mass)

371 and also in single-meal experiments (Couturier 2007). In contrast, the portion of AS allocated to

372 SDA in turbot, Scophthalmus maximus, was temperature dependent: at $7^{\circ} \mathrm{C}$, the SDA mobilized

$37329 \%$ of the AS compared to $52 \%$ at $16^{\circ} \mathrm{C}$ (Mallekh and Lagardère 2002). The AS of sole and

374 turbot can be $\sim 1.2$ and 1.7 times higher than that of the Greenland halibut, respectively (Mallekh

375 and Lagardère 2002; Lefrançois and Claireaux 2003). In Atlantic cod, Gadus morhua, or

376 European seabass, Dicentrarchus labrax, which have AS values larger than flatfish, the SDA can

377 mobilize respectively $68 \%$ and $20 \%$ of AS (Jordan and Steffensen 2007; Dupont-Prinet et al. 
378 2010). Such variability among studies may reflect methodological differences (e.g. meal size,

379 temperature), or species differences (e.g. inter-specific metabolic differences, pathway for 380 nutrient handling. Such differences could also be related to the level of metabolic scope or to the

381 proportion of the scope that can be allocated to SDA. Some species spend more time swimming 382 than others and therefore need greater flexibility to respond to swim-muscle demands.

384 In Greenland halibut, aerobic capacity that is not used for digestive processes can be required for 385 foraging activity. This species has been described as a "voracious, bathypelagic predator" (Scott 386 and Scott 1988), and many of its important prey species are pelagic, such as capelin, redfishes, 387 shrimp, and cephalopods (Bowering and Lilly 1992; Rodriguez-Marin et al. 1995; Jørgensen 388 1997; Michalsen and Nedreaas 1998; Savenkoff et al. 2007; Solmundsson 2007; Dwyer et al. 389 2010). Holmes and Gibson (1983) also showed that other flatfishes hunt in the water column and 390 indicate that this was the case for $70 \%$ of attacks of the turbot Scophtalmus maximus. Greenland

391 halibut require some aerobic capacity above that used for SDA to be able to feed before their

392 previous meal is completely digested. Furthermore, it is likely that field values of $\dot{M}_{2}$ peak 393 regularly exceed what was observed in this study. Meals can be larger in the field, since the ration 394 we used was about $90 \%$ of a full stomach in wild Greenland halibut. Furthermore, continuous

395 feeding over several days increases $\dot{\mathrm{MO}}_{2 \text { peak }}$ considerably compared to a single meal (Soofiani and 396 Hawkins 1982).

\section{Aerobic scope of juveniles in hypoxia}

399 The general trend of a decrease in AS as a function of ambient DO caused by a limitation of 400 MMR agrees with previous studies in other teleosts (Jobling 1982; Schurmann and Steffensen 
401 1992; Van den Thillart et al. 1994; Crocker and Ceck 1997; Claireaux and Lagardère 1999;

402 Mallekh and Lagardère 2002; Jourdan-Pineau et al. 2009; Dupont-Prinet et al. 2009; Pörtner and 403 Peck 2010). It is well known that metabolic rate is influenced by environmental factors, 404 particularly temperature and DO level. Fry (1971) considered temperature to be a factor 405 controlling metabolic rate and DO to be a limiting factor. Although we observed a significant 406 decrease in MMR between normoxia and hypoxia (28, 23, and 19\% sat.), we did not observe 407 significant differences in MMR between the three levels of hypoxia even though 19\% sat. is close 408 to the critical oxygen threshold in juveniles. Biological variability and sample size could partly 409 explain the lack of significant differences in MMR according to ANOVA. Biological variability 410 was less pronounced with AS, where each fish served as its own control (both MMR and SMR 411 were measured on the same fish). In this case, there was a further decline in AS at $19 \%$ sat. 412 compared with 28 and $23 \%$.

413

414 At $19 \%$ sat., the AS of juvenile Greenland halibut was only $28 \%$ of the AS recorded at $100 \%$ sat. 415 Therefore, we expected both a reduction in the amplitude and an increase in the duration of SDA 416 when juveniles were exposed to hypoxia after feeding (Jordan and Steffensen 2007; Zhang et al. 417 2010b). Though there was a tendency for $\dot{M}_{O_{2} \text { peak }}$ and thus amplitude to be lower in severe 418 hypoxia than in normoxia, only duration was significantly altered in hypoxia: SDA lasted $25 \%$ 419 longer at $21 \%$ sat. than at $100 \%$ sat. This finding suggests that juvenile Greenland halibut cannot 420 process food as quickly or eat as frequently at $21 \%$ sat. as they can at $100 \%$ sat. Consequently, 421 juvenile growth rate may be reduced at this level of hypoxia. 
423 Although our results show little effect of severe hypoxia (21\% sat.) on SDA, they indicate that

424 Greenland halibut living in the St. Lawrence Estuary is at the edge of its metabolic capacity since 425 the encountered oxygen level is close to the $\mathrm{O}_{2 \text { crit }}$ for this species. The deterioration of oxygen 426 conditions could have several consequences. Wild fish living at non-limiting DO levels are likely

427 to feed frequently. As reported above, continuous feeding increases $\dot{\mathrm{M}}_{2 \text { peak }}$ over what is observed 428 with a single meal (Soofiani and Hawkins 1982). Considering that $\dot{M}_{2}$ peak mobilized up to $75 \%$ 429 of AS in our single-meal experiment, it is possible that $\dot{\mathrm{M}}_{2}$ peak would become limited by DO in 430 fish continuously feeding in severely hypoxic conditions (Wang et al. 2009). Although this has 431 yet to be studied, a lower $\dot{M}_{2}$ peak should result in a longer SDA and lower overall rate of food 432 consumption compared to normoxia.

433

434 Wild fish may avoid investing such a large proportion of their AS in SDA. In this study, fish fed 435 freely in normoxia before being placed in hypoxia for SDA. They did not have the opportunity to 436 adjust their ration to digest in hypoxic conditions. But in the St. Lawrence Estuary, Greenland 437 halibut likely have to feed in severe hypoxia, even though they may capture some of their prey in 438 the water column. Therefore, fish may adjust their food consumption to their capacity to provide 439 the energy necessary for digestion while leaving sufficient flexibility for other needs like 440 swimming. It has recently been demonstrated that the sea bass, Dicentrarchus labrax, cannot 441 meet swimming and SDA demands simultaneously in hypoxic conditions and that it will 442 prioritize aerobic exercise performance over SDA (Dupont-Prinet et al. 2009; Jourdan-Pineau et 443 al. 2009). On the contrary, when temperature increases, SDA is prioritized over exercise 444 performance in juvenile southern catfish, Silurus meridionalis (Pang et al. 2010). Clearly, both 445 swimming and feeding are critical functions for survival: swimming to catch prey and feeding to 
446 provide energy and to grow. Because the cost of food assimilation increases with food intake,

447 reducing the postprandial $\dot{M}_{2}$ peak by reducing food ingestion is an obvious way to cope with 448 hypoxia (Soofiani and Hawkins 1982; Mallekh and Lagardère 2002). Hypoxia usually results in

449 decreased conversion efficiency (Stewart et al. 1967; Fry 1971; Edwards et al. 1972; Andrews et

450 al. 1973; Brett and Blackburn 1981; Pedersen 1987; Wilhelm Filho et al. 2005; Jordan and 451 Steffensen 2007). This will compound the impact of a reduced rate of food consumption on 452 growth.

454 Environmental hypoxia has a direct influence on fisheries in two very important ways. First, 455 hypoxia can limit the productivity of a species. Reduced growth rate and survival (because of 456 hypoxia and increased predation) in fish could be due to the quantitative and qualitative decrease 457 in performance because of a reduction in AS (Breitburg 2002). Greenland halibut supports an 458 economically important fishery in the EGSL. Even though our results indicate that Greenland 459 halibut can tolerate fairly severe hypoxia, they show that aerobic scope is greatly reduced at 460 hypoxia levels presently encountered in the St. Lawrence Estuary and indicate that present levels 461 of DO severely constrain the aerobic metabolism in this species. This is especially true in 462 juveniles for which a reduction in growth rate cannot be excluded. A reduction in growth rate 463 would be a major concern because $16 \%$ of the Greenland halibut biomass, including a high 464 concentration of young fish aged 1 or 2 years, is found in the St. Lawrence Estuary (MPO 2010). 465 Consequently, recruitment of this species could be affected if dissolved oxygen conditions 466 worsened. Second, hypoxia may control species' interactions in natural populations. Indeed, 467 hypoxia can concentrate fish prey by reducing their distribution area, which improves predation 468 efficiency and contributes to the increase in predator numbers (Breitburg 2002; Eby et al. 2005; 
469 Costantini et al. 2008; Zhang et al., 2010b; Brandt et al. 2011). This short-term positive effect of

470 hypoxia for predators is counter-balanced by a long-term negative effect because the over-

471 consumption of prey and the decrease of suitable habitat for predators induces a density-

472 dependent reduction of predator growth rates and health (Breitburg 2002; Eby et al. 2005;

473 Costantini et al. 2008; Zhang et al. 2010a; Brandt et al. 2011). It also results in a decrease in

474 overall biomass and biodiversity.

475

476 Since the mid-1980s, DO levels in the deep waters of the EGSL have been stable (Gilbert et al., 477 2007). However, the factors responsible for the previous DO decline in the deep waters of the St.

478 Lawrence Estuary could occur again, and possibly be enhanced by global climate changes. Thus

479 any change in oceanographic patterns that would enhance the proportion of North Atlantic

480 Central Water entering the Laurentian Channel, or any human-induced increase in nutrient 481 loading in the St. Lawrence River, would result in a further deterioration in DO levels in the 482 Estuary. This could very well impact the growth rate and/or distribution of Greenland halibut in 483 both the Estuary and Gulf of St. Lawrence. Our results indicate the need for an ecophysiological 484 approach in the study of the constraints imposed on fishes to improve fisheries management. 485

\section{Acknowledgements}

487 The authors are grateful to Y. Lambert for providing the fish and to T. Hansen, J. Gagnon, L. 488 Girard, and J.-G. Rondeau for help with the experiments and assistance in caring for the fish.

\section{$490 \quad$ Funding}

491 This project was funded entirely by the Natural Sciences and Engineering Research Council of

492 Canada (Strategic grant No. STPGP 365115-08 to C. Audet, D. Gilbert, Y. Lambert, D. Chabot, 
493 and R. Tremblay), Fisheries and Oceans Canada, the Réseau Aquaculture Québec, and the Fonds

494 de Recherche du Québec - Nature et Technologies (post-doctoral scholarship to M. Vagner).

495

496 
497

498

500

501

502

503

504

505

506

507

508

509

510

511

512

513

514

515

516

517

518

\section{References}

Ait Youcef, W., Lambert, Y., and Audet, C. 2013. Spatial distribution of Greenland halibut Reinhardtius hippoglossoides in relation to abundance and hypoxia in the Estuary and Gulf of St. Lawrence. Fish. Oceanogr. 22: 41-60. Early view. DOI: 10.1111/fog.12004.

Andrews, J.W., Murai, T., and Gibbons, G. 1973. The influence of dissolved oxygen on the growth of channel catfish. Trans. Am. Fish. Soc. 102: 835-838.

Bourdages, H., Archambault, D., Bernier, B., Fréchet, A., Gauthier, J., Grégoire, F., Lambert, J., and Savard, L. 2010. Preliminary results from the groundfish and shrimp multidisciplinary survey in August 2010 in the northern Gulf of St. Lawrence. DFO Can. Sci. Advis. Sec. Res. Doc. 2010/107. vi +92 p.

Bowering, W.R., and Lilly, G.R. 1992. Greenland halibut (Reinhardtius hippoglossoides) off Southern Labrador and Northeastern Newfoundland (Northwest Atlantic) feed primarily on capelin (Mallotus villosus). Neth. J. Sea. Res. 29: 211-222. doi:10.1016/00777579(92)90021-6.

Brandt, S. B., Costantini, M., Kolesar, S., Ludsin, S. A., Mason, D. M., Rae, C. M., and Zhang, H. Y. 2011. Does hypoxia reduce habitat quality for Lake Erie walleye (Sander vitreus)? A bioenergetics perspective. Can. J. Fish. Aquat. Sci. 68: 857-879. doi:10.1139/F2011-018.

Breitburg, D. 2002. Effects of hypoxia, and the balance between hypoxia and enrichment, on coastal fishes and fisheries. Estuaries 25: 767-781. doi: 10.1007/BF02804904.

Brett, J.R. 1979. Environmental factors and growth. In Fish Physiology, vol. 8, Bioenergetics and Growth. Edited by W. S. Hoar, D. J. Randall, and J. R. Brett. Academic Press, New York, pp. 599-675. 
519 Brett, J.R., and Blackburn, J.M. 1981. Oxygen requirements for growth of young coho 520 (Oncorhynchus kisutch) and sockeye (O. nerka) salmon at $15^{\circ} \mathrm{C}$. Can. J. Fish. Aquat. Sci. 38: 399-404. doi:10.1139/f81-056.

Brett, J.R., and Groves, T.D.D. 1979. Physiological energetics. In Fish Physiology, vol. 8, Bioenergetics and Growth. Edited by W. S. Hoar, D. J. Randall, and J. R. Brett. Academic Press, New York. pp. 279-352.

Burleson, M.L., Wilhelm, D.R., and Smatresk, N.J. 2001. The influence of fish size on the avoidance of hypoxia and oxygen selection by largemouth bass. J. Fish Biol. 59: 13361349. doi:10.1006/jfbi.2001.1745.

Cech, J., Mitchell, S., and Wragg, T. 1984. Comparative growth of juvenile white sturgeon and striped bass: Effects of temperature and hypoxia. Estuaries Coasts. 7: 12-18. doi: $10.2307 / 1351952$.

Cerezo, J., and García, B.G. 2004. The effects of oxygen levels on oxygen consumption, survival and ventilatory frequency of sharpsnout sea bream (Diplodus puntazzo Gmelin, 1789) at different conditions of temperature and fish weight. J. Appl. Ichthyol. 20: 488-492. doi:10.1111/j.1439-0426.2004.00601.x

Chabot, D., and Dutil, J.D. 1999. Reduced growth of Atlantic cod in non-lethal hypoxic 536 conditions. J. Fish Biol. 55: 472-491. doi: 10.1111/j.1095-8649.1999.tb00693.x

Chabot, D., and Claireaux, G. 2008. Environmental hypoxia as a metabolic constraint on fish: the case of Atlantic cod, Gadus morhua. Mar. Poll. Bull. 57: 287-294. doi:10.1016/j.marpolbul.2008.04.001. exercise and cardiac performance in the European seabass (Dicentrarchus labrax). Mar. Biol. 147: 855-862. doi: 10.1007/s00227-005-1624-7. 
543 Chatelier, A., McKenzie, D.J., Prinet, A., Galois, R., Robin, J., Zambonino, J., and Claireaux, G.

544 2006. Associations between tissue fatty acid composition and physiological traits of 545 performance and metabolism in the seabass (Dicentrarchus labrax). J. Exp. Biol. 209: 546 3429-3439. doi: 10.1242/jeb.02347.

547 Claireaux, G., and Lagardère, J.P. 1999. Influence of temperature, oxygen and salinity on the 548 metabolism of the European sea bass. J. Sea Res. 42: 157-168. doi: 10.1016/S1385$549 \quad 1101(99) 00019-2$.

550 Coote, A.R., and Yeats, P.A. 1979. Distribution of nutrients in the Gulf of St. Lawrence. J. Fish. 551 Res. Board Can. 36: 122-131. doi:10.1139/f79-021.

552 Costantini, M., Ludsin, S. A., Mason, D. M., Xinsheng, Z., Boicourt, W. C., and Brandt, S. B. 553 2008. Effect of hypoxia on habitat quality of striped bass (Morone saxatilis) in Chesapeake 554 Bay. Can. J. Fish. Aquat. Sci. 65: 989-1002. doi: 10.1139/F08-021.

555 Couturier, C. 2007. Effets des caractéristiques physico-chimiques et biorhéologiques de l'eau sur 556 la physiologie, les performances adaptatives et la sélection de l'habitat chez la sole 557 commune Solea solea (Linnaeus, 1758). PhD thesis. Université de La Rochelle, France.

558 Crocker, C.E., and Cech, J.J. 1997. Effects of environmental hypoxia on oxygen consumption 559 rate and swimming activity in juvenile white sturgeon, Acipenser transmontanus, in relation 560 to temperature and life intervals. Environ. Biol. Fishes 50: 383-389. 561 doi:10.1023/A:1007362018352.

562 D'Amours, D. 1993. The distribution of cod (Gadus morhua) in relation to temperature and 563 oxygen level in the Gulf of St. Lawrence. Fish. Oceanogr. 2:24-29. doi: 10.1111/j.1365$564 \quad$ 2419.1993.tb00009.x. 
565 Daoud, D., Chabot, D., Audet, C., and Lambert, Y. 2007. Temperature induced variation in oxygen consumption of juvenile and adult stages of the northern shrimp, Pandalus borealis. J. Exp. Mar. Biol. Ecol. 347: 30-40. doi: 10.1016/j.jembe.2007.02.013.

Davoodi, F., and Claireaux, G. 2007. Effects of exposure to petroleum hydrocarbons upon the metabolism of the common sole Solea solea. Mar. Poll. Bull. 54: 928-934. doi:10.1016/j.marpolbul.2007.03.004

Department of Fisheries and Oceans. 2011. Quebec Marine Fisheries - Landing Statistics by Species, December 2011, 59 p.

Dorcas, M.E., Hopkins, W.A., and Roe, J.H. 2004. Effects of body mass and temperature on standard metabolic rate in the eastern diamondback rattlesnake (Crotalus adamanteus). Copeia, 145-151. doi: 10.1643/CP-03-074R1.

Dupont-Prinet, A., Claireaux, G., and McKenzie, D.J. 2009. Effects of feeding and hypoxia on cardiac performance and gastrointestinal blood flow during critical speed swimming in the sea bass Dicentrarchus labrax. Comp. Biochem. Physiol. A Mol. Integr. Physiol. 154: 233240. doi: 10.1016/j.cbpa.2009.06.015.

Dupont-Prinet, A., Chatain, B., Grima, L., Vandeputte, M., Claireaux, G., and McKenzie, D.J. 2010. Physiological mechanisms underlying a trade-off between growth rate and tolerance

Dwyer, K.S., Buren, A., and Koen-Alonso, M. 2010. Greenland halibut diet in the Northwest of feed deprivation in the European sea bass (Dicentrarchus labrax). J. Exp. Biol. 213: Atlantic from 1978 to 2003 as an indicator of ecosystem change. J. Sea Res. 64: 436-445. doi: 10.1016/j.seares.2010.04.006. 
587

588

589

590

591

592

593

594

595

596

597

598

599

600

601

602

603

604

605

606

607

608

609

610

Eby, L. A., Crowder, L. B., McClellan, C. M., Peterson, C. H., and Powers, M. J. 2005. Habitat degradation from intermittent hypoxia: impacts on demersal fishes. Mar. Ecol. Prog. Ser. 291: 249-261. doi: 10.3354/meps291249.

Edwards, R. R. C., Finlayson, D. M., and Steele, J. H. 1972. An experimental study of the oxygen consumption, growth, and metabolism of the cod (Gadus morhua L.). J. Exp. Mar. Biol. Ecol. 8: 299-309.

Frisk, M., Skov, P. V., and Steffensen, J. F. 2012. Thermal optimum for pikeperch (Sander lucioperca) and the use of ventilation frequency as a predictor of metabolic rate. Aquaculture. 324: 151-157. doi:10.1016/j.aquaculture.2011.10.024.

Fry, F.E.J. 1971. The effect of environmental factors on the physiology of fish. In Environmental Relations and Behavior (VI). Edited by W.S. Hoar and D.J. Randall. Academic Press, New York, pp. 1-98.

Garcia, H.E., and Gordon, L.I. 1992. Oxygen solubility in seawater - better fitting equations. Limnol. Oceanogr. 37: 1307-1312.

Genovesi, L., de Vernal, A., Thibodeau, B., Hillaire-Marcel, C., Mucci, A., and Gilbert, D. 2011. Recent changes in bottom water oxygenation and temperature in the Gulf of St. Lawrence: Micropaleontological and geochemical evidence. Limnol. Oceanogr. 56: 1319-1329. doi: 10.4319/1o.2011.56.4.1319.

Gilbert, D., Sundby, B., Gobeil, C., Mucci, A., and Tremblay, G.-H. 2005. A seventy-two-year record of diminishing deep-water oxygen in the St. Lawrence estuary: The northwest Atlantic connection. Limnol. Oceanogr. 50: 1654-1666.

Gilbert, D., Chabot, D., Archambault, P., Rondeau, B., and Hébert, S. 2007. Appauvrissement en oxygène dans les eaux profondes du Saint-Laurent marin : Causes possibles et impacts écologiques. Nat. Can. 131: 67-75. 
611 Holmes, R.A., and Gibson, N. 1983. A comparison of predatory behaviour in flatfish. Anim. 612 Behav. 31: 1244-1255. doi: 10.1016/S0003-3472(83)80031-1.

613 Jobling, M. 1981. Mathematical models of gastric-emptying and the estimation of daily rates of 614 food consumption for fish. J. Fish Biol. 19: 245-257. doi: 10.1111/j.1095$615 \quad$ 8649.1981.tb05829.x.

616 Jobling, M. 1982. A study of some factors affecting rates of oxygen consumption of plaice, 617 Pleuronectes platessa L. J. Fish Biol. 20: 501-516. doi: 10.1111/j.1095$618 \quad$ 8649.1982.tb03951.x.

619 Jobling, M. 1983. Towards an explanation of Specific Dynamic Action (SDA). J. Fish Biol. 23: 620 549-555. doi: 10.1111/j.1095-8649.1983.tb02934.x.

621 Jordan, A.D., and Steffensen, J.F. 2007. Effects of ration size and hypoxia on specific dynamic 622 action in the cod. Physiol. Biochem. Zool. 80: 178-185. doi: 10.1086/510565.

623 Jørgensen, O.A. 1997. Pelagic occurrence of Greenland halibut, Reinhardtius hippoglossoides 624 (Walbaum), in west Greenland waters. J. Northw. Atl. Fish. Sci. 21: 39-50.

625 Jourdan-Pineau, H., Dupont-Prinet, A., Claireaux, G., and McKenzie, D.J. 2009. An investigation 626 of metabolic prioritization in the European sea bass, Dicentrarchus labrax. Physiol. $627 \quad$ Biochem. Zool. 83: 68-77. doi: 10.1086/648485.

628 Koenker, R. 2005. Quantile regression. Cambridge University Press, Cambridge. 366 p.

629 Koenker, R. 2011. Quantreg: Quantile Regression. R package version 4.67. http://CRAN.R$630 \quad$ project.org/package $=$ quantreg.

631 Lefrançois, C., and Claireaux, G. 2003. Influence of ambient oxygenation and temperature on 632 metabolic scope and scope for heart rate in the common sole Solea solea. Mar. Ecol. Prog. 633 Ser. 259: 273-284. doi: 10.3354/meps259273. 
634 Liao, Y.Y., and Lucas, M.C. 2000. Growth, diet and metabolism of common wolf-fish in the 635 North Sea, a fast-growing population. J. Fish Biol. 56: 810-825. doi: 10.1111/j.1095$636 \quad$ 8649.2000.tb00874.x.

637 Lucas, M.C., and Priede, I.G. 1992. Utilization of metabolic scope in relation to feeding and 638 activity by individual and grouped zebrafish, Brachydanio rerio (Hamilton-Buchanan). J. Fish Biol. 41: 175-190. doi: 10.1111/j.1095-8649.1992.tb02648.x

640 Mallekh, R., and Lagardère, J.P. 2002. Effect of temperature and dissolved oxygen concentration 641 on the metabolic rate of the turbot and the relationship between metabolic scope and feeding demand. J. Fish Biol. 60: 1105-1115. doi: 10.1006/jfbi.2002.1918.

643 McCue, M.D. 2006. Specific dynamic action: A century of investigation. Comp. Biochem. 644 Physiol. A Mol. Integr. Physiol. 144: 381-394. doi:10.1016/j.cbpa.2006.03.011.

645 Michalsen, K., and Nedreaas, K.H. 1998. Food and feeding of Greenland halibut (Reinhardtius 646 hippoglossoides, Walbaum) in the Barents Sea and East Greenland waters. Sarsia 83: 401-

648 Milinkovitch, T., Lucas, J., Le Floch, S., Thomas-Guyon, H., and Lefrançois, C. 2012. Effect of 649 dispersed crude oil exposure upon the aerobic metabolic scope in juvenile golden grey 650 mullet (Liza aurata). Mar. Poll. Bull. 64: 865-871. doi: 10.1016/j.marpolbul.2012.01.023.

651 MPO (Pêches et Océans Canada). 2010. Évaluation du stock de flétan du Groenland du golfe du 652 Saint-Laurent (4RST) en 2009. Secr. can. de consult. sci. du MPO, Avis sci. 2010/028.

653 Nelson, J.A., and Chabot, D. 2011. General energy metabolism. In Encyclopedia of fish 654 physiology: from genome to environment, vol. 3. Edited by A.P. Farrell. Academic Press, 655 San Diego, pp. 1566-1572.

656 Pang, X., Cao, Z.-D., Peng, J.-L. and Fu, S.-J. 2010. The effects of feeding on the swimming 657 performance and metabolic response of juvenile southern catfish, Silurus meridionalis, 

253-258. doi.org/10.1016/j.cbpa.2009.11.005.

Pedersen, C.L. 1987. Energy budgets for juvenile rainbow trout at various oxygen concentrations. Aquaculture 62: 289-298. doi: 10.1016/0044-8486(87)90171-2.

Plante, S., Chabot, D., and Dutil, J.D. 1998. Hypoxia tolerance in Atlantic cod. J. Fish Biol. 53: 1342-1356. doi: 10.1006/jfbi.1998.0798.

Pörtner, H. O. 2010. Oxygen- and capacity-limitation of thermal tolerance: a matrix for 665 integrating climate-related stressor effects in marine ecosystems. J. Exp. Biol. 213: 881-

Pörtner, H. O., and Peck, M. A. 2010. Climate change effects on fishes and fisheries: towards a cause-and-effect understanding. J. Fish Biol. 77: 1745-1779. doi: 10.1111/j.10958649.2010.02783.x.

R Development Core Team 2011. R: A language and environment for statistical computing. $\mathrm{R}$ Foundation for Statistical Computing, Vienna, Austria. ISBN 3-900051-07-0, URL http://www.R-project.org/.

Reidy, S.P., Nelson, J.A., Tang, Y., and Kerr, S.R. 1995. Post-exercise metabolic rate in Atlantic cod and its dependence upon the method of exhaustion. J. Fish Biol. 47: 377-386. doi: 10.1111/j.1095-8649.1995.tb01907.x.

Rodriguez-Marin, E., Punzón, A., and Paz, J. 1995. Feeding patterns of Greenland halibut (Reinhardtius hippoglossoides) in Flemish Pass (Northwest Atlantic). NAFO Sci. Coun. Studies. 23: 43-54.

Savenkoff, C., Castonguay, M., Chabot, D., Hammill, M.O., Bourdages, H., and Morissette, L. 2007. Changes in the northern Gulf of St. Lawrence ecosystem estimated by inverse 

724. doi: 10.1016/j.ecss.2007.03.011.

Schurmann, H., and Steffensen, J.F. 1992. Lethal oxygen levels at different temperatures and the preferred temperature during hypoxia of the Atlantic cod, Gadus morhua L. J. Fish Biol. 41: 927-934. doi: 10.1111/j.1095-8649.1992.tb02720.x.

Scott, W.B., and Scott, M.G. 1988. Atlantic fishes of Canada. Can. Bull. Fish. and Aquat. Sci. University of Toronto Press. Toronto.

Secor, S. M. 2009. Specific dynamic action: a review of the postprandial metabolic response. J. Comp. Physiol. B Biochem. Syst. Environ. Physiol. 179: 1-56. doi:10.1007/s00360-008-

Sheridan, J.A., and Bickford, D. 2011. Shrinking body size as an ecological response to climate 0283-7.

Solmundsson, J. 2007. Trophic ecology of Greenland halibut (Reinhardtius hippoglossoides) on the Icelandic continental shelf and slope. Mar. Biol. Res. 3: 231-242. doi:

Soofiani, N.M., and Hawkins, A.D. 1982. Energetic costs at different levels of feeding in juvenile cod, Gadus morhua L. J. Fish Biol. 21: 577-592. doi: 10.1111/j.1095-8649.1982.tb02861.x.

Steffensen, J.F. 1989. Some errors in respirometry of aquatic breathers - How to avoid and correct for them. Fish Physiol. Biochem. 6: 49-59. doi: 10.1007/BF02995809.

Stewart, N.E., Shumway, D.L., and Doudorff, P. 1967. Influence of oxygen concentration on

702 Switzer, T. S., Chesney, E. J., and Baltz, D. M. 2009. Habitat selection by flatfishes in the 703 northern Gulf of Mexico: Implications for susceptibility to hypoxia. J. Exp. Mar. Biol. Ecol. 381: S51-S64. doi: 10.1016/j.jembe.2009.07.011. 
705 Thibodeau, B., de Vernal, A., and Mucci, A. 2006. Recent eutrophication and consequent

706

707

708

709

710

711

712

713

714

715

716

717

718

719

720

721

722

723

724

725

726

727

728

hypoxia in the bottom waters of the Lower St. Lawrence Estuary: Micropaleontological and geochemical evidence. Mar. Geol. 231: 37-50. doi: 10.1016/j.margeo.2006.05.010.

Thibodeau, B., de Vernal, A., Hillaire-Marcel, C., and Mucci, A. 2010. Twentieth century warming in deep waters of the Gulf of St. Lawrence: A unique feature of the last millennium. Geophys. Res. Lett. 37. doi: 10.1029/2010GL044771.

Van den Thillart, G., Dalla Via, J., Vitali, G., and Cortesi, P. 1994. Influence of long-term hypoxia exposure on the energy metabolism of Solea solea. 1. Critical $\mathrm{O}_{2}$ levels for aerobic and anaerobic metabolism. Mar. Ecol. Prog. Ser. 104: 109-117.

Wang, T., Lefevre, S., Huong, D.T.T, and Van Cong, M. 2009. The effects of hypoxia on growth and digestion. In Fish Physiology, vol. 27, Hypoxia. Edited by A.P. Farrell and C.J. Brauner. Academic Press/ Elsevier, San Diego, pp. 396-361.

Weber, J.-M., and Kramer, D.L. 1983. Effects of hypoxia and surface access on growth, mortality, and behavior of juvenile guppies, Poecilia reticulata. Can. J. Fish. Aquat. Sci. 40: 1583-1588. doi:10.1139/f83-183.

Wilhelm Filho, D., Torres, M.A., Zaniboni-Filho, E., and Pedrosa, R.C. 2005. Effect of different oxygen tensions on weight gain, feed conversion, and antioxidant status in piapara, Leporinus elongatus (Valenciennes, 1847). Aquaculture, 244: 349-357. doi: 10.1016/j.aquaculture.2004.11.024.

Zahl, I., Kiessling, A., Samuelsen, O., and Olsen, R. 2010. Anesthesia induces stress in Atlantic salmon (Salmo salar), Atlantic cod (Gadus morhua) and Atlantic halibut (Hippoglossus hippoglossus). Fish Physiol. Biochem. 36: 719-730. doi: 10.1007/s10695-009-9346-2.

Zhang, W., Cao, Z.-D., Peng, J.-L., Chen, B.-J., and Fu, S.-J. 2010b. The effects of dissolved oxygen level on the metabolic interaction between digestion and locomotion in juvenile 
729 southern catfish (Silurus meridionalis Chen). Comp. Biochem. Physiol. - Part A. 157: 212$730 \quad$ 219. doi: $10.1016 /$ j.cbpa.2010.06.184.

731 Zhang, J., Gilbert, D., Gooday, A. J., Levin, L., Naqvi, S. W. A., Middelburg, J. J., Scranton, M., 732 Ekau, W., Pena, A., Dewitte, B. et al. 2010a. Natural and human-induced hypoxia and 733 consequences for coastal areas: synthesis and future development. Biogeosciences 7: 1443734 1467. doi: $10.5194 /$ bg-7-1443-2010. 


\section{$736 \quad$ Figure legends}

737 Figure 1. Oxygen consumption $\left(\dot{\mathrm{MO}}_{2}, \mathrm{mg} \mathrm{O}_{2} \cdot \mathrm{h}^{-1} \cdot \mathrm{kg}^{-1}\right)$ as a function of $\mathrm{DO}(\%$ sat.) for an

738 individual Greenland halibut. $\mathrm{O}_{2 \text { crit }}$ is the intercept of the standard metabolic rate (SMR, grey line)

739 and the regression line (black line) through the points below SMR. The scatter of points at $100 \%$

740 sat. corresponds to data recorded during the $48 \mathrm{~h}$ prior to the gradual decrease in DO level, and

741 thus include values recorded during spontaneous activity of fish.

742 Figure 2. Oxygen consumption $\left(\dot{\mathrm{MO}}_{2}, \mathrm{mg} \mathrm{O}_{2} \cdot \mathrm{h}^{-1} \cdot \mathrm{kg}^{-1}\right)$ over time (h:m) recorded immediately after

743 intense exercise in Greenland halibut juveniles. Standard metabolic rate (SMR) is symbolized by

744 the light grey line on each panel. Two estimates of maximum $\dot{M}_{\mathrm{O}_{2}}$ were calculated for each fish.

745 First, the post-exercise maximum $\dot{\mathrm{M}}_{2}$ was estimated using data recorded within one hour (three

746 readings) of placing the fish in the respirometer: the highest of the first three post-exercise $\dot{M}_{2}$

747 (unfilled dot) was retained (panel A). Second, the maximum spontaneous $\mathrm{M}_{2}$ during $\geq$ two days

748 inside the respirometer was estimated as the $0.99^{\text {th }}$ quantile $\dot{\mathrm{M}}_{2}$ (dark grey line, panel B). The

749 higher of the two estimates was retained as maximum $\dot{M}_{2}$ (MMR) for the fish. Grey areas in

750 panel B indicate night periods. Note that these two examples are from two different fish.

751 Figure 3. Oxygen consumption $\left(\dot{\mathrm{MO}}_{2}, \mathrm{mg} \mathrm{O}_{2} \cdot \mathrm{h}^{-1} \cdot \mathrm{kg}^{-1}\right)$ over the post-feeding time in Greenland

752 halibut juveniles (see text for details). SMR is the standard metabolic rate (in $\mathrm{mg} \mathrm{O}_{2} \cdot \mathrm{h}^{-1} \cdot \mathrm{kg}^{-1} ; \mathrm{grey}$

753 line) calculated at the end of experiment. A non-parametric quantile regression $(\tau=0.15, \lambda=36)$

754 was fitted to the postprandial $\dot{M}_{2}$ measurements until SMR $+10 \%$. Peak (net) is the amplitude of

755 SDA, thus $\dot{M}_{2 \text { peak }}$ (maximum post-prandial peak of $\dot{M}_{2}$ ) is $\mathrm{SMR}+$ peak (net); $\mathrm{T}_{\text {peak }}(\mathrm{h}$ ) is the

756 time to reach $\dot{\mathrm{MO}}_{2 \text { peak }}$; duration (h) is the time required to return to $\mathrm{SMR}+10 \%$ after feeding; 
757 magnitude is the total oxygen consumption during digestion $\left(\mathrm{mg} \mathrm{O}_{2} \cdot \mathrm{kg}^{-1}\right)$. Grey areas indicate 758 night periods.

759 Figure 4. Linear relationship between the standard metabolic rate of each individual (SMR ind $_{3} \mathrm{mg}$

$760 \mathrm{O}_{2} \cdot \mathrm{h}^{-1}$ ) and the wet body mass $(\mathrm{g})$ of Greenland halibut at $5^{\circ} \mathrm{C}$. All data were $\log$ transformed.

761 The black solid lines represent the linear regression for juveniles (on the left: $\log (\mathrm{SMR}$ ind $)=$ $7620.9072 \cdot \log ($ mass $\left.)-1.2846 ; \mathrm{R}^{2}=0.44\right)$ and adults (on the right: $\log \left(\mathrm{SMR}_{\text {ind }}\right)=0.9766 \cdot \log ($ mass $)$

$\left.763-1.6771 ; \mathrm{R}^{2}=0.71\right)$. The dashed line represents the overall linear regression: $\log \left(\mathrm{SMR}_{\text {ind }}\right)=$

$764 \quad 0.7708 \cdot \log (\operatorname{mass})-1.0247\left(\mathrm{R}^{2}=0.96\right)$.

765 Figure 5. Mean ( $\pm 0.95 \%$ confidence interval) rates of post-prandial oxygen uptake (mg

$766 \mathrm{O}_{2} \cdot \mathrm{h}^{-1} \cdot \mathrm{kg}^{-1}$ ) over time in normoxia (dark grey) and hypoxia at $21 \%$ sat. (light grey). The non-

767 parametric fit for each was used to predict a value of $\dot{\mathrm{M}}_{2}$ at $0.5 \mathrm{~h}$ intervals after feeding. The

768 average value and its $95 \%$ confidence interval were computed for each treatment. 
Table 1: Fork length (FL), mass, standard metabolic rate (SMR), and critical oxygen level $\left(\mathrm{O}_{2 \text { crit }}\right)$ in adult $(\mathrm{N}=14)$ and juvenile $(\mathrm{N}=12)$ Greenland halibut (mean \pm s.e.m.). $\mathrm{P}$ is the probability of a difference between adults and juveniles.

\begin{tabular}{lccc} 
& Adults & Juveniles & P \\
\cline { 2 - 4 } & $51 \pm 1.1$ & $23 \pm 0.5$ & $<0.001$ \\
FL (cm) & $1465 \pm 114$ & $91 \pm 6$ & $<0.001$ \\
SMR (g) $\left(\mathrm{mg} \mathrm{O}_{2} \cdot \mathrm{h}^{-1} \cdot \mathrm{kg}^{-1}\right)$ & $18.02 \pm 0.84$ & $36.20 \pm 1.53$ & $<0.001$ \\
$\mathrm{O}_{2 \text { crit }}(\%$ sat. $)$ & $11.10 \pm 0.72$ & $14.89 \pm 0.92$ & 0.003 \\
\hline
\end{tabular}


Table 2: Effects of dissolved oxygen (\% sat.) on aerobic metabolism in juvenile Greenland halibut. Oxygen treatments: normoxia (100\% sat.) or hypoxia $(28,23$, and $19 \%$ sat.), fork length (FL), standard (SMR) and maximum metabolic rate (MMR), aerobic scope (AS), (means \pm s.e.m.). $\mathrm{N}=12,11,10$, and 13 at 100, 28, 23, and 19\% sat., respectively. FL, mass, and SMR were not significantly different among treatments. Within a row, means with different letters were statistically different.

Dissolved oxygen

\begin{tabular}{cccc}
\hline $100 \%$ & $28 \%$ & $23 \%$ & $19 \%$ \\
\hline $21 \pm 0.2$ & $21 \pm 0.6$ & $21 \pm 0.7$ & $21 \pm 0.6$ \\
$80 \pm 3$ & $80 \pm 8$ & $73 \pm 8$ & $82 \pm 7$ \\
$38.79 \pm 1.33$ & $29.60 \pm 2.17$ & $31.83 \pm 4.12$ & $32.00 \pm 1.94$ \\
$125.85 \pm 7.85^{\mathrm{b}}$ & $68.41 \pm 5.23^{\mathrm{a}}$ & $66.87 \pm 5.50^{\mathrm{a}}$ & $56.38 \pm 2.81^{\mathrm{a}}$ \\
$87.06 \pm 7.66^{\mathrm{c}}$ & $38.81 \pm 3.82^{\mathrm{b}}$ & $35.04 \pm 2.93^{\mathrm{ab}}$ & $24.38 \pm 2.72^{\mathrm{a}}$ \\
& & & \\
\hline
\end{tabular}


Table 3: Effects of hypoxia (21\% sat.) on the postprandial metabolic response (specific dynamic action, SDA) in juvenile Greenland halibut. Mean ( \pm s.e.m.), N=10 in normoxia, and $\mathrm{N}=7$ in hypoxia. Fork length (FL); mass; $\mathrm{SMR}\left(\mathrm{mg} \mathrm{O} 2 \cdot \mathrm{h}^{-1} \cdot \mathrm{kg}^{-1}\right) ; \dot{M}_{2 \text { peak }}$ is the maximum oxygen consumption observed during SDA; amplitude is the difference between peak oxygen consumption and SMR; $\mathrm{T}_{\text {peak }}$ is the time required to reach $\dot{\mathrm{M}}_{2 \text { peak }}$; duration is the time required to return to $\mathrm{SMR}+10 \%$ after feeding; magnitude is the total oxygen consumed during digestion. $\mathrm{P}$ is the probability of a difference between normoxia and hypoxia.

\begin{tabular}{|c|c|c|c|}
\hline & & & \\
\hline & Normoxia & Hypoxia & $\mathrm{P}$ \\
\hline & $(100 \%)$ & $(21 \%)$ & \\
\hline $\mathrm{FL}(\mathrm{cm})$ & $21 \pm 0.4$ & $21 \pm 0.3$ & 0.247 \\
\hline $\operatorname{Mass}(\mathrm{g})$ & $78 \pm 6$ & $72 \pm 5$ & 0.412 \\
\hline $\operatorname{SMR}\left(\mathrm{mg} \mathrm{O}_{2} \cdot \mathrm{h}^{-1} \cdot \mathrm{kg}^{-1}\right)$ & $33.54 \pm 1.90$ & $31.85 \pm 2.39$ & 0.585 \\
\hline$\dot{\mathrm{M}}_{2 \text { peak }}\left(\mathrm{mg} \mathrm{O}_{2} \cdot \mathrm{h}^{-1} \cdot \mathrm{kg}^{-1}\right)$ & $54.46 \pm 2.47$ & $50.18 \pm 3.43$ & 0.314 \\
\hline Amplitude $\left(\mathrm{mg} \mathrm{O}_{2} \cdot \mathrm{h}^{-1} \cdot \mathrm{kg}^{-1}\right)$ & $20.91 \pm 1.52$ & $18.33 \pm 2.37$ & 0.350 \\
\hline $\mathrm{T}_{\text {peak }}(\mathrm{h})$ & $27.85 \pm 6.81$ & $47.93 \pm 15.47$ & 0.206 \\
\hline Duration (h) & $117.70 \pm 8.69$ & $147.14 \pm 10.77$ & 0.049 \\
\hline $\begin{array}{c}\text { Magnitude } \\
\text { (area under the curve } \\
\mathrm{mg} \mathrm{O}_{2} \cdot \mathrm{kg}^{-1} \text { ) }\end{array}$ & $1507.24 \pm 79.56$ & $1736.12 \pm 158.26$ & 0.178 \\
\hline
\end{tabular}




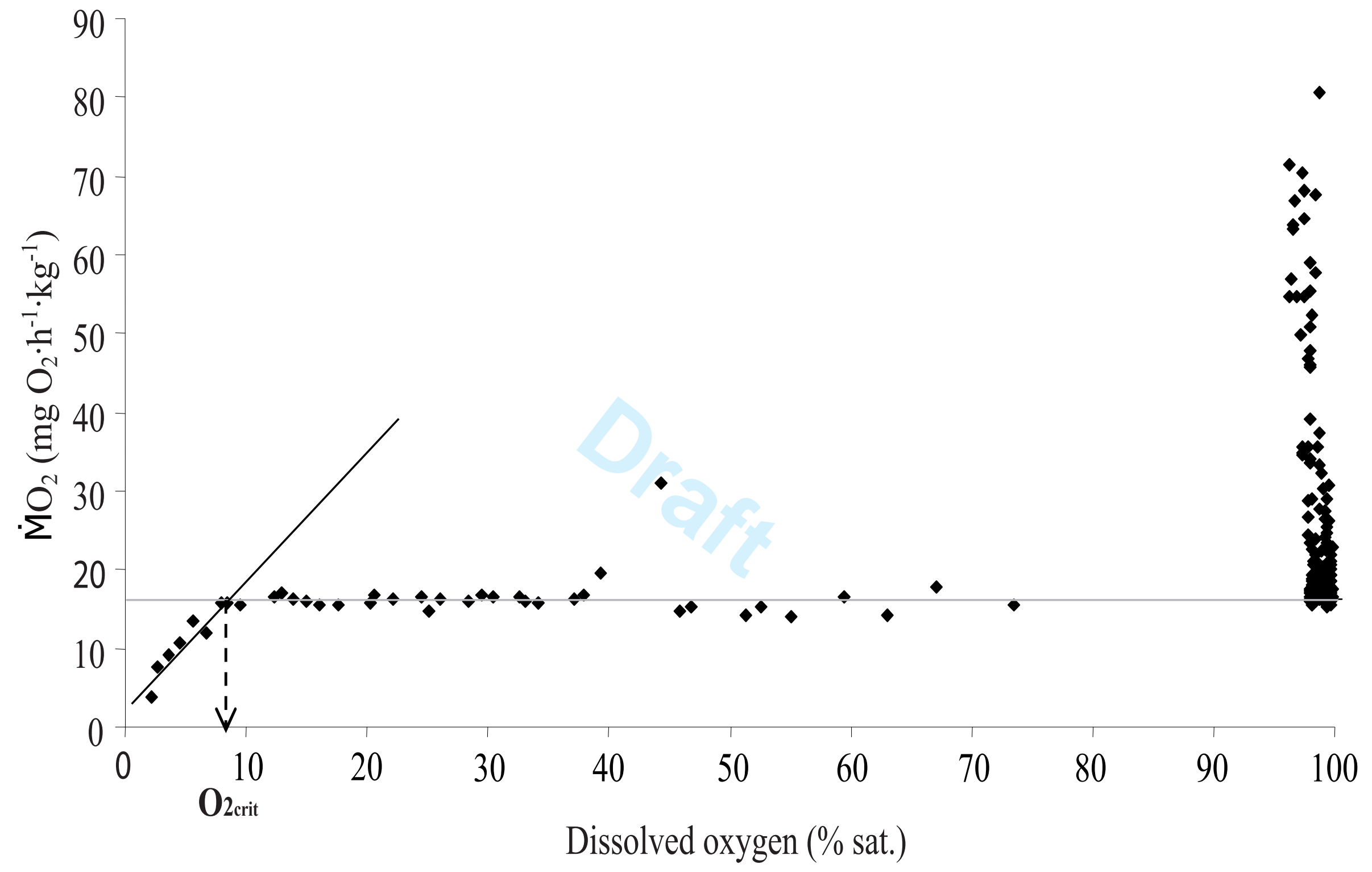




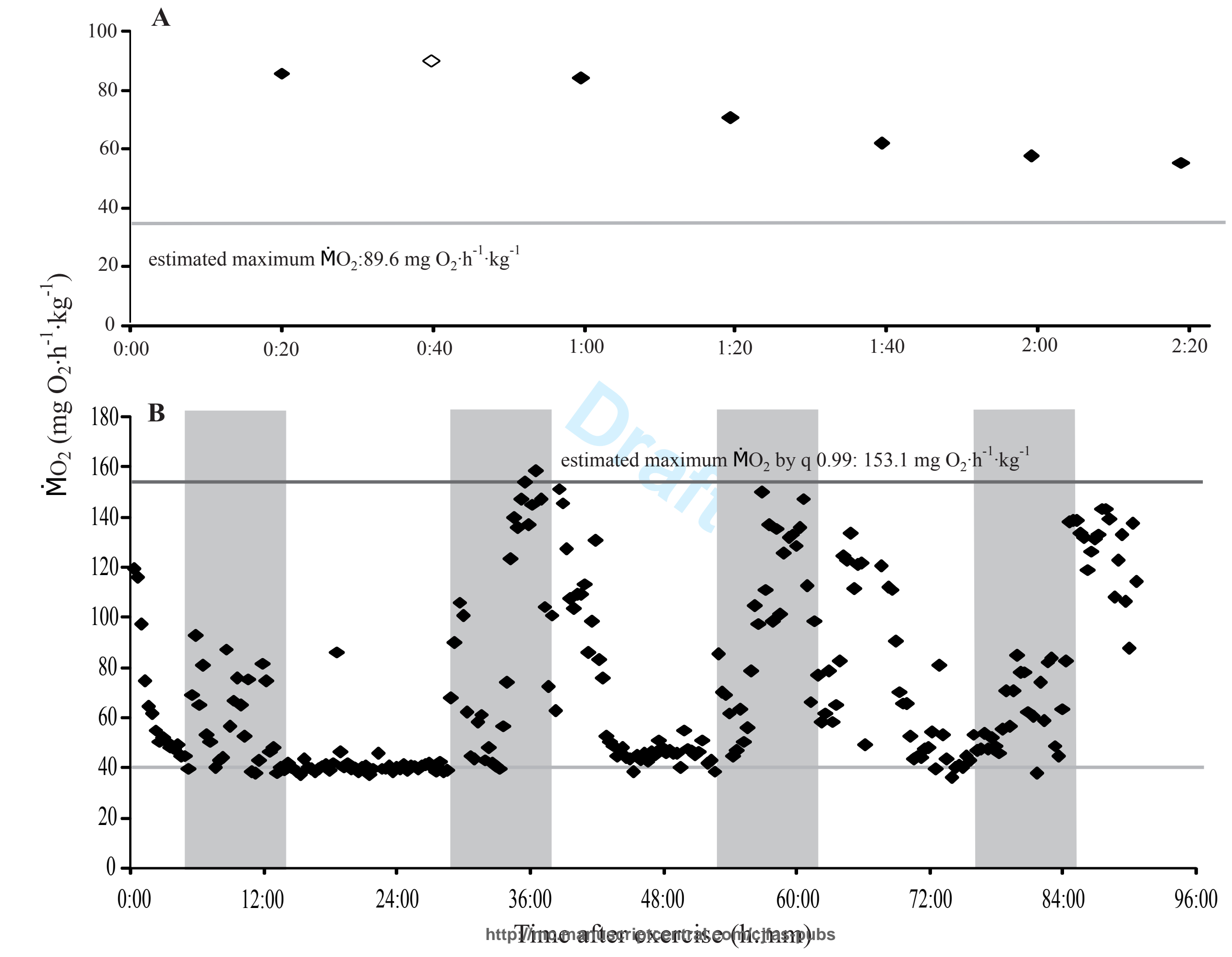




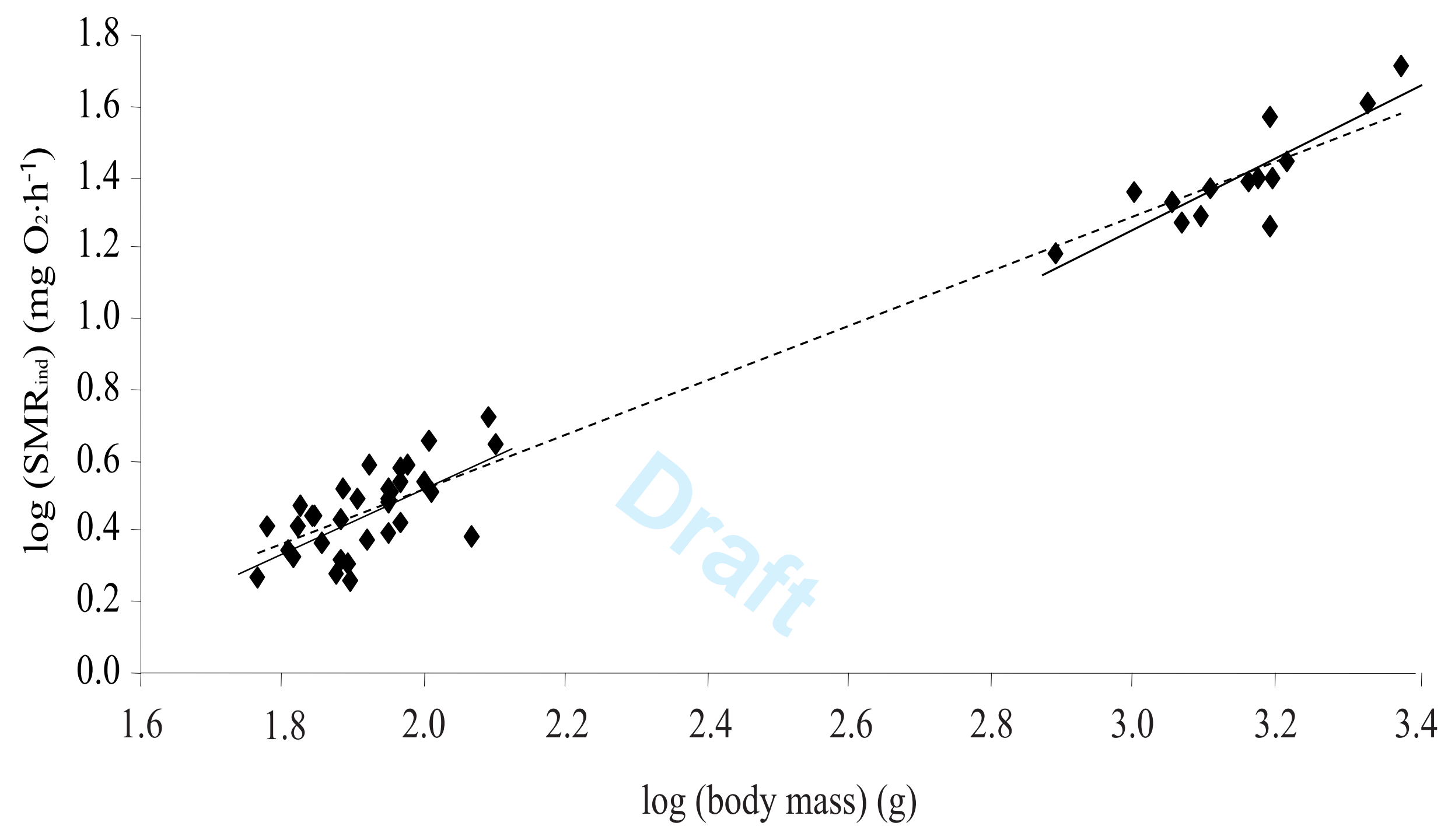




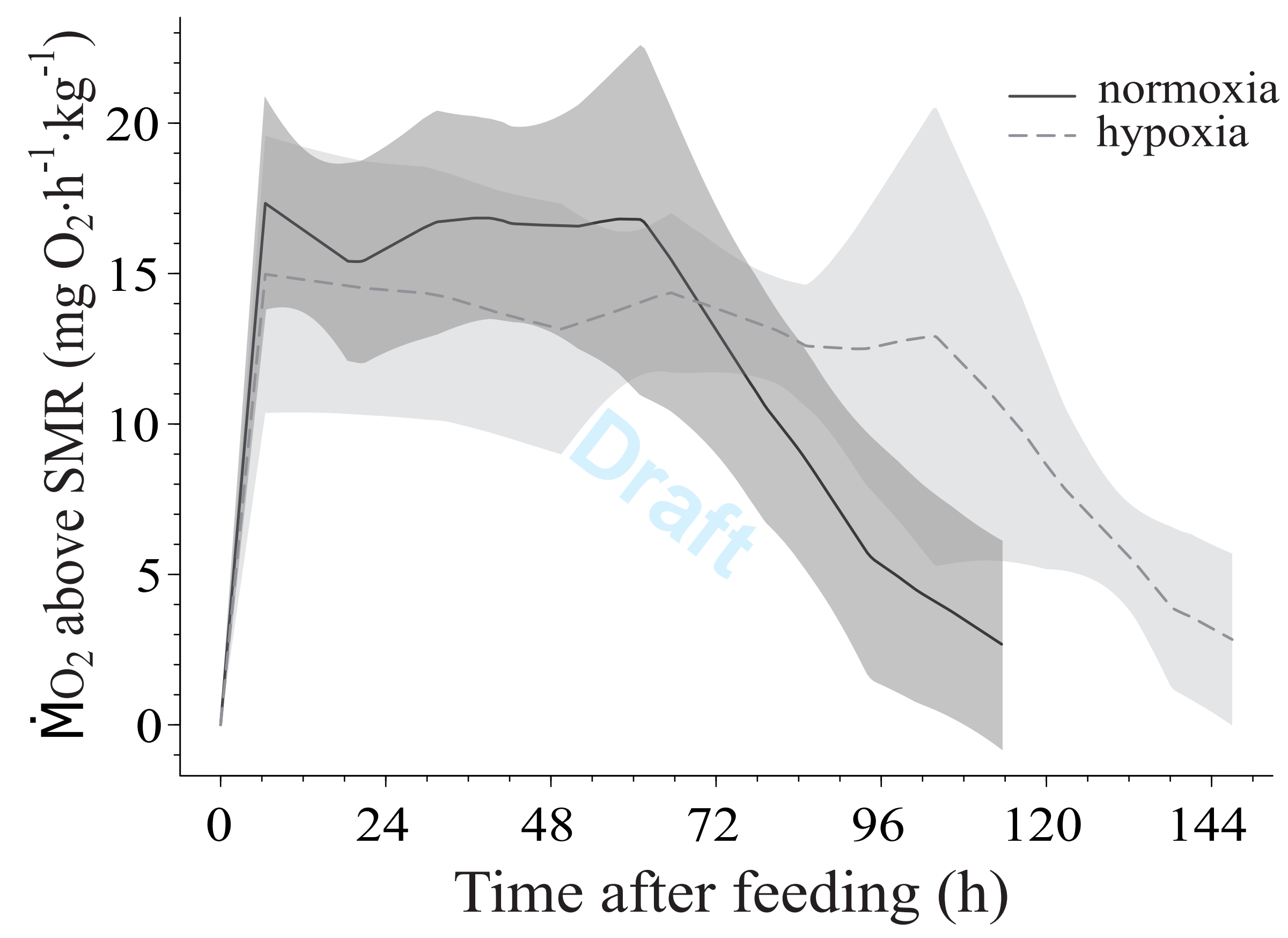

